Int. J. Electrochem. Sci., 14 (2019) 7062 - 7075

\title{
Synthesis, Spectroscopic and Electrochemical Study of Mn(II) Complexes of N-methylbenzyl, Phenylpiperazyl- and Morpholinyl- dithiocarbamate
}

\author{
Fartisincha P. Andrew, Peter A. Ajibade* \\ School of Chemistry and Physics, University of KwaZulu-Natal, Private Bag X01, Scottsville, \\ Pietermaritzburg, 3209 South Africa \\ *E-mail: ajibadep@ukzn.ac.za \\ doi: $10.20964 / 2019.08 .14$
}

Received: 4 July 2018 / Accepted: 5 September 2018 / Published: 30 June 2019

$\mathrm{Mn}(\mathrm{II})$ complexes of N-methylbenzyl- $\left(\mathrm{L}_{1}\right)$, phenylpiperazyl- $\left(\mathrm{L}_{2}\right)$ and morpholinyl- ( $\left.\mathrm{L}_{3}\right)$ dithiocarbamates formulated as $\left[\mathrm{Mn}\left(\mathrm{L}_{1}\right)_{2}\right] \mathbf{1},\left[\mathrm{Mn}\left(\mathrm{L}_{2}\right)_{2}\right] \mathbf{2}$ and $\left[\mathrm{Mn}\left(\mathrm{L}_{3}\right)_{2}\right] \mathbf{3}$ were synthesized and characterized by elemental analysis and spectroscopic techniques. The FTIR spectra confirmed the dithiocarbamate molecules coordinated the $\mathrm{Mn}(\mathrm{II})$ ion as bidentate chelating ligands by the single $v(\mathrm{C}$ S) bands observed in the range $940-994 \mathrm{~cm}^{-1}$ and the $v(\mathrm{C}-\mathrm{N})$ stretching vibrations observed in the region1462-1483 $\mathrm{cm}^{-1}$. The EPR studies of the compounds showed broad signals for complexes 1 and 3 with $g$ values of 2.223 and 2.164 at $25{ }^{\circ} \mathrm{C}$ and 2.005 and 2.013 at $-196{ }^{\circ} \mathrm{C}$ respectively and hyperfine coupling constant $(A)$ of 98.65 and $84.64 \mathrm{G}$ respectively. Complex 2 showed six lines hyperfine splitting typical of ${ }^{55} \mathrm{Mn}$ nucleus, with $g$ values of 2.144 and 2.082 at $25^{\circ} \mathrm{C}$ and $-196{ }^{\circ} \mathrm{C}$ respectively and hyperfine coupling constant of 93.47 . The electrochemical studies of the complexes revealed two redox couples for complexes 1 and 3 at a potential range of -0.4 to $0.5 \mathrm{~V}$ and -0.29 to $0.42 \mathrm{~V}$ respectively with each redox couple associated with a sequential single electron transfer process corresponding to the $\mathrm{Mn}^{\mathrm{II}} / \mathrm{Mn}^{\mathrm{III}}$ and $\mathrm{Mn}^{\mathrm{III}} / \mathrm{Mn}^{\mathrm{IV}}$ metal center redox process. Complex 1 exhibited one redox couple at 0.5 to $1.2 \mathrm{~V}$ potential corresponding to metal center $\mathrm{Mn}^{\mathrm{II}} / \mathrm{Mn}^{\mathrm{III}}$ redox process. All the complexes exhibited diffusion controlled behaviour at increase scan with the ratio of cathodic to anodic peak current approximately a unity.

Keywords: Manganese(II); dithiocarbamates; spectroscopy; electrochemistry; cyclic voltammetry.

\section{FULL TEXT}

(C) 2019 The Authors. Published by ESG (www.electrochemsci.org). This article is an open access article distributed under the terms and conditions of the Creative Commons Attribution license (http://creativecommons.org/licenses/by/4.0/). 